\title{
A taxonomic revision of the genus Dolomiaea (Asteraceae: Cardueae) in India
}

\author{
Kasana S., Uniyal P.L. \& A.K. Pandey* \\ Department of Botany, University of Delhi, Delhi - 110 007, India \\ *E-mail: arunpandey79@gmail.com
}

\begin{abstract}
The genus Dolomiaea DC. (Asteraceae: Cardueae) is represented by three species in India. It is distributed in the alpine Himalaya and is often found in chasmophytic habitats. Recent advances in molecular phylogenetic studies have re-circumscribed the generic boundaries of Dolomiaea and hence a detailed taxonomic account of this genus in India is provided here. We recognize three species: Dolomiaea baltalensis Dar \& Naqshi, D. costus (Falc.) Kasana \& A.K.Pandey and D. macrocephala DC. ex Royle for India. Dolomiaea macrocephala and the heterotypic synonym of D. costus, Aplotaxis lappa Decne. are lectotypified.
\end{abstract}

Keywords: Lectotype, Nomenclature, Saussureinae, Taxonomy, Western Himalaya.

\section{Introduction}

The genus Dolomiaea DC. (Asteraceae: Cardueae) is represented by c. 21 species worldwide and is endemic to the alpine regions of China, India, Myanmar, Nepal and Pakistan (Huang, 1998; Wang et al., 2007; Funk et al., 2009; Shi \& RaabStraube, 2011; Shen et al., 2020). It is one of the well-established genera in subtribe Saussureinae N.Garcia \& Susanna (earlier informally known as the Saussurea or Saussurea - Jurinea group) and occurs up to $5000 \mathrm{~m}$ elevation.

The genus was established by Candolle (1833) honouring French geologist Deodat de Dolomieu. According to the protologue, Dolomiaea is closely related to Saussurea DC. and this concept was accepted for a long time until Boissier (1888) shifted

Received: 31.10.2020; Revised \& Accepted: 24.02.2021

Published Online: 31.03 .2021 the type species to Jurinea Cass., indicating its close affinity with Jurinea. It was treated under Jurinea section Subacaules Benth. by Bentham and Hooker (1873) in their Genera Plantarum and this treatment was followed by most other botanists including Hooker (1881) and Hajra (1995). However, Ling (1965) treated Dolomiaea as a separate genus more closely related to Saussurea than to Jurinea, based on the morphology of the pappus, corolla and pollen grains. The genus Vladimiria Iljin was also included within the circumscription of Dolomiaea by Ling (1965) and was recognized as a section based on similarities in habit and inflorescence. Although the infrageneric limits within the present day subtribe Saussureinae have remained unclear for a long time (Susanna \& Garcia-Jacas, 2009; Raab-Straube, 2017; Herrando-Moraira et al., 2020), grouping of genus Dolomiaea into two sections has been widely accepted (Chu, 1986; Wang et al., 2007): (i) D. sect. Dolomiaea characterized by short, compact style branches with round apex and (ii) D. sect. Vladimiria (Iljin) C.Shih with long, spreading and acute style branch tips.

Dolomiaea has been characterized morphologically by naked and alveolate receptacles, pluriseriate pappi and scabrid pappus bristles (Wang et al., 2007). However, there are many ambiguities in the circumscription of this genus due to the presence of overlapping characters and phenotypic plasticity. Therefore, Dolomiaea has been of great interest for systematists and has remained an integral part of the Saussurea - Jurinea group. However, recent studies have shown that Dolomiaea is a distinct genus and has been recovered as a well-supported 
clade in molecular analyses (Wang et al., 2007; Herrando-Moraira et al., 2020; Kasana et al., 2020).

The genus is medicinally important and some of the species such as D. souliei (Franch.) C.Shih, and D. wardii (Hand.-Mazz.) Y.Ling are known to exhibit anti-bacterial activity and have been used traditionally as herbal medicines (Li \& Sheng, 2013). Dolomiaea macrocephala DC. ex Royle (also referred to in various publications as Jurinea dolomiaea Boiss.) is popularly used for its aromatic roots in the incense industry, as an insect repellent and also to treat fever, rheumatism, gout, etc. (Sharma et al., 2004). It has also been reported to be forage for the alpine lagomorph Ochotona roylei Ogilby, commonly known as Himalayan mouse hare or Royle's pika (Bhattacharyya et al., 2013).

In India, Dolomiaea is represented by three species distributed in the Himalaya (Fig. 1). As the genus is medicinally important and has undergone various taxonomic changes in recent years, a comprehensive account in India has been provided in the present communication with details on phenology, distribution, conservation status and type information.

\section{Taxonomic treatment}

Dolomiaea DC. in Guillem., Arch. Bot. (Paris) 2: 330. 1833; Hook. f., Fl. Brit. Ind. 3(8): 378. 1881; Dar \& Naqshi, J. Bombay Nat. Hist. Soc. 87(2): 278. 1990; Karthik. et al., Fl. Pl. India 1:321. 2009. Type: Dolomiaea macrocephala DC. ex Royle.

Perennial herbs, mostly acaulescent, rarely longstemmed. Leaves dentate to pinnatifid, rarely entire; ovate, obovate or lanceolate, adaxial surface mostly hirsute spinulose, abaxial surface usually densely woolly. Capitula solitary to numerous, always homogamous, arranged in centre of leaf rosette, rarely terminal. Involucre campanulate, bracts multiseriate. Receptacle alveolate, without scales. Corolla pentamerous, actinomorphic, purple to purplish-blue, glabrous to gland dotted. Staminal filaments glabrous; anthers sagittate, tails lacerate. Cypsela obovate, obpyramidal or broadly obconic, isodiametric, apical pericarpal rim glabrous, sometimes rugulose to squamulose, straw-coloured, often with black wavy fringes. Pappus uni- or multiseriate, subequal or outer row shorter; bristles yellowish, scabrid or plumose; basally connate into a ring, caducous as a whole.

Habitat: It is found in alpine regions in chasmophytic habitats like rock crevices, open slopes or dry areas.

Distribution: China, India, Myanmar, Nepal and Pakistan.

Notes: With the advancement of molecular techniques, several phylogenetic studies (Wang et al., 2007; Susanna \& Garcia-Jacas, 2009; Shen et al., 2020) have been carried out to investigate the systematic position of Dolomiaea and to assess its generic limits. In recent studies (HerrandoMoraira et al., 2020; Kasana et al., 2020) the genus has been re-circumscribed to include the genera Aucklandia Falc., Bolocephalus Hand.-Mazz. and Frolovia (DC.) Lipsch. It has also been suggested now that Dolomiaea is more closely related to Jurinea and not to Saussurea as was earlier believed.

\section{Key to the species in India}

1. Capitula terminal on stems; pappus uniseriate D. costus

1. Capitula clustered in leaf rosettes; pappus multiseriate .. 2

2. Leaves adaxially tomentose, entire to irregularly lobed. D. baltalensis

2. Leaves adaxially hirsute, pinnatifid D. macrocephala

Dolomiaea baltalensis Dar \& Naqshi, J. Bombay Nat. Hist. Soc. 87(2): 278. 1990. Type: INDIA, Kashmir, Baltal, Sonmarg, Sind valley, G.H. Dar 3899 (holo KASH; iso KASH, E [E00385497 digital image!]).

Fig. 2

Perennial herbs, acaulescent. Leaves ovate to elliptic ovate, rounded at the base, $13-16 \times 5-7 \mathrm{~cm}$, entire to irregularly lobed, dentate, adaxial surface 


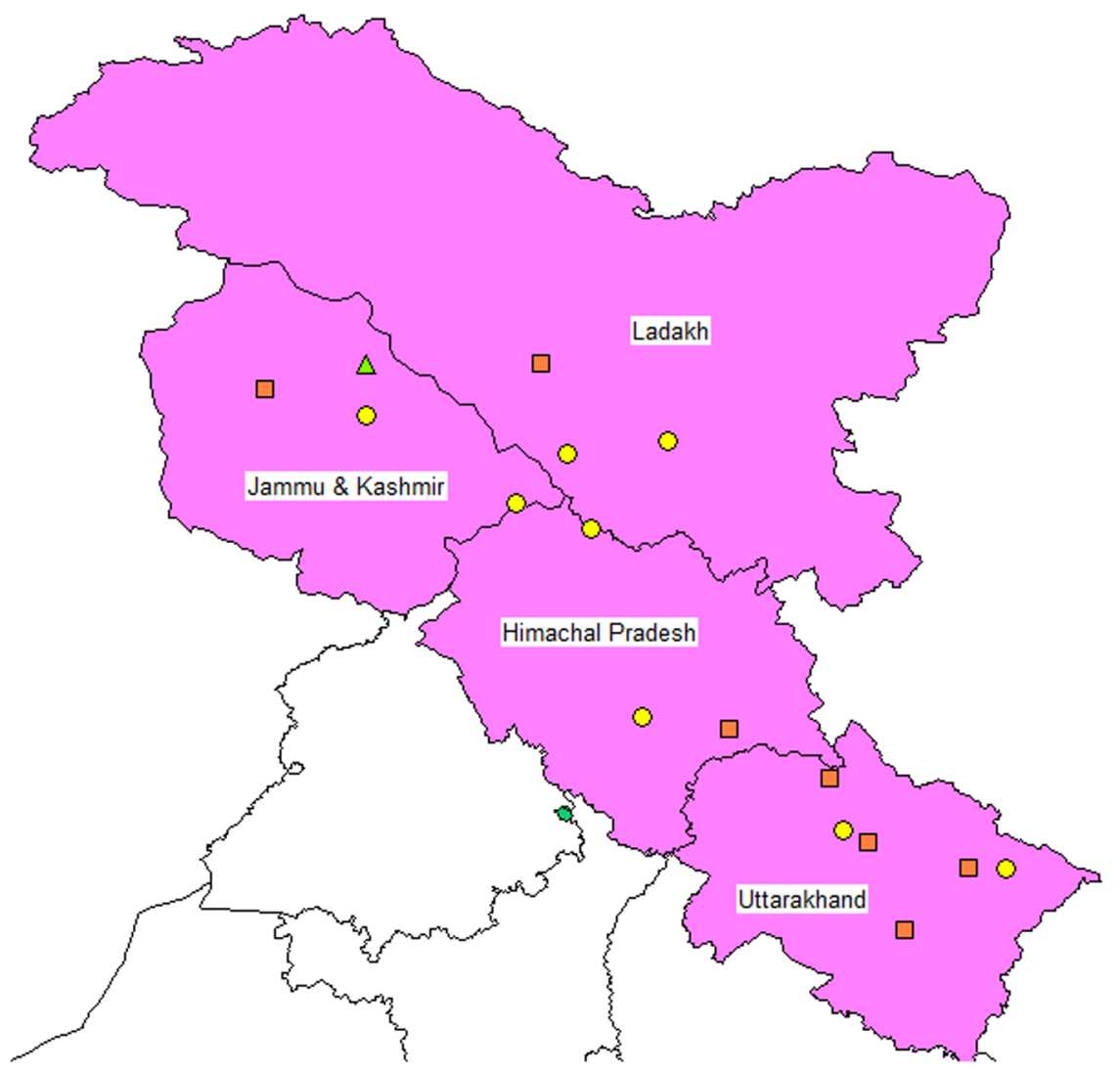

$\triangle$ Dolomiaea baltalensis

0 Dolomiaea costus

$\square$ Dolomisea macrocephala

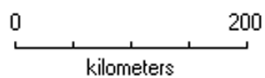

Fig. 1. Distribution map of the genus Dolomiaea DC. in Guillem. in India, showing some of the specimens examined in this study (drawn using DIVA-GIS).

tomentose, abaxial surface densely woolly, petiolate. Petiole 3 to $10 \mathrm{~cm}$ long, woolly, sometimes sheathing at the base. Capitula numerous, 7-24 in number, $1.5-2.2 \times 0.5-1.5 \mathrm{~cm}$, discoid, peduncle up to $5 \mathrm{~cm}$. Involucral bracts in many rows, acuminate, ovate-lanceolate, imbricate. Florets actinomorphic. Corolla tubular, pinkish-purple, up to $1.5 \mathrm{~cm}$ long. Staminal filaments glabrous; anthers sagittate, tails lacerate. Cypsela cuneate-obovoid, 4-angled with an apical pericarpal rim, glabrous, 2.1-2.7 × 0.7-0.9 mm, grey with black wavy fringes. Pappus multiseriate with scabrid bristles, unequal, brown, deciduous as a whole.

Flowering \& fruiting: Flowering and fruiting from August to September.

Habitat: It grows on rocky slopes above meadows elevations of 3000 to $3500 \mathrm{~m}$.

Distribution: India, endemic to Jammu \& Kashmir.
Specimens examined: INDIA, Jammu \& Kashmir, Baltal, Sonmarg, Sind valley, 3000 m, 02.09.1982, G.H. Dar 3899 (E [E00385497 digital image]); Pranshur, Sonmarg, Sind valley, $3500 \mathrm{~m}$, 27.08.1983, G.H. Dar 8325 (E [E00385498 digital image]).

Conservation status: This species is a point endemic and known only from the type locality, with only a few mature individuals. Since the type collection it has not been collected from any other potential localities (Singh \& Pusalkar, 2020), and its habitat is also facing threats due to deforestation, unregulated road constructions etc. Therefore, the species is assessed here as Critically Endangered [criteria D] as per the guidelines of IUCN (2019).

Notes: Dolomiaea baltalensis is most similar to D. macrocephala in general appearance but differs from the taxon by its tomentose adaxial leaf surface, entire 

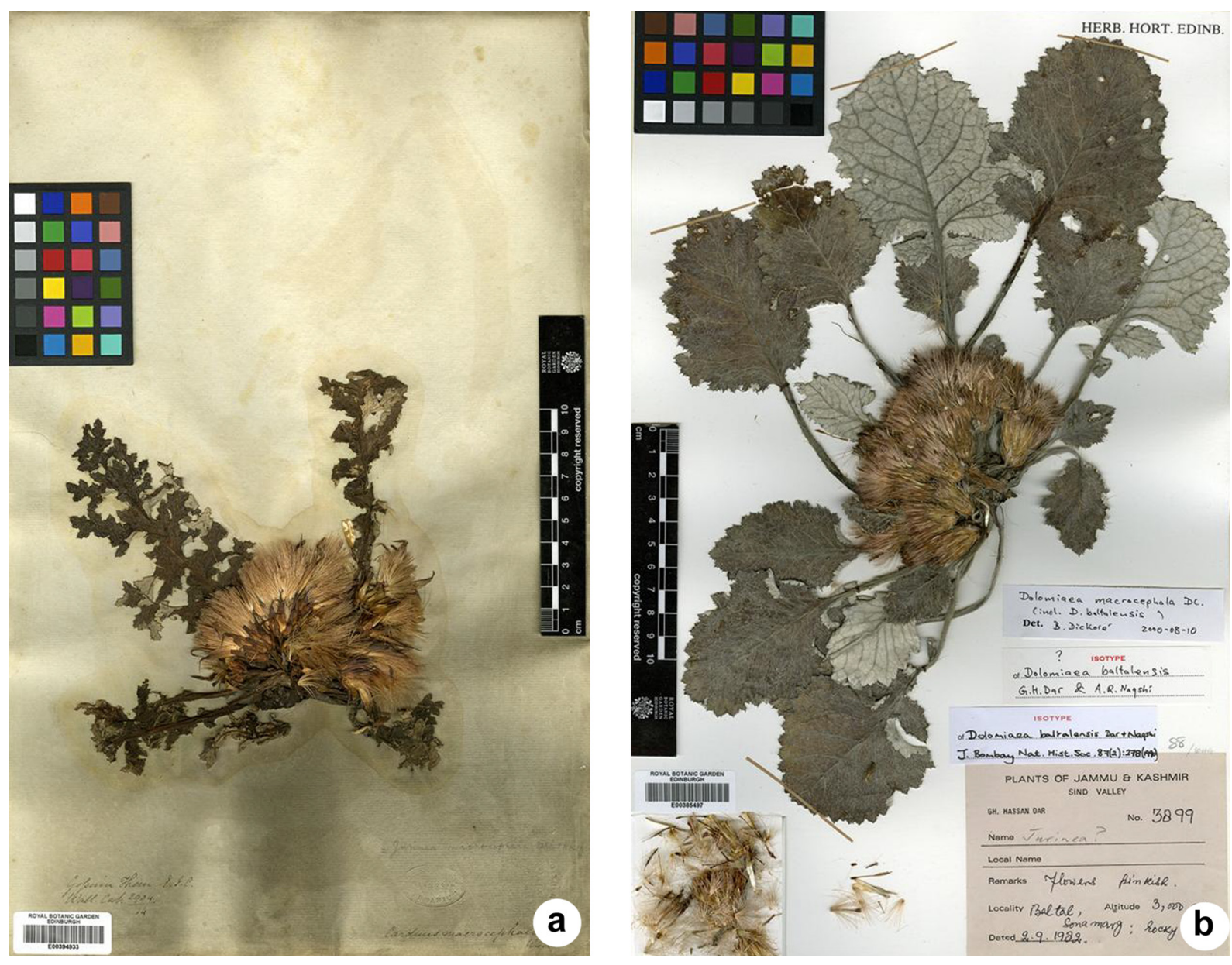

Fig. 2. Type images of a. Dolomiaea baltalensis Dar \& Naqshi (http://data.rbge.org.uk/herb/E00394933) and b. Dolomiaea macrocephala DC. ex Royle (http://data.rbge.org.uk/herb/E00385497) (@ Royal Botanic Garden, Edinburgh.)

to irregularly lobed leaf lamina and longer peduncles $(0.5-4.5 \mathrm{~cm}$ long) against hirsute adaxial leaf surface, pinnatifid leaves and shorter peduncles (0.5-1.5 cm long) in D. macrocephala.

Dolomiaea costus (Falc.) Kasana \& A.K.Pandey, Phytotaxa 450(2): 184. 2020. Aucklandia costus Falc., Ann. Mag. Nat. Hist. 6: 475. 1841. Theodorea costus Kuntze, Revis. Gen. Pl. 1:368. 1891. Saussurea costus (Falc.) Lipsch., Bot. Zhurn. (Moscow \& Leningrad) 49: 131. 1964. Lectotype (designated by Lipschitz, 1979): INDIA, Kashmir, Falconer s.n. (K [K000372736 digital image!]).

Aplotaxis lappa Decne., Voy. Inde [Jacquemont] 4 (Bot.): 96, t. 104. 1844. Saussurea lappa (Decne.) Sch.Bip., Linnaea 19(3): 331. 1846. Saussurea lappa (Decne.) C.B.Clarke, Compos. Ind. 233. 1876, isonym. Aucklandia lappa (Decne.) Decne., Iconogr.
Cormophyt. Sin. 4: 643, f. 6700. 1875. Lectotype (designated here): INDIA, Kashmir, V. Jacquemont 727 (P [P00602864 digital image!]).

Fig. 3

Perennial herbs, erect, 1-3 m tall. Stem simple, pubescent above, $0.8-2 \mathrm{~cm}$ in diam. Basal leaves membranous, 10-12 × 7-9 cm, irregularly toothed; petiole $4-30 \mathrm{~cm}$, lobately winged. Cauline leaves sessile or shortly petiolate, $14-16 \times 9-11 \mathrm{~cm}$. Leaves gland dotted or pubescent abaxially, hirsute adaxially, margin dentate or mucronate, apex acute. Capitula homogamous, sessile, solitary or in cluster of $3-5$, usually terminal, $2.5-3.5 \times 1.5-2 \mathrm{~cm}$. Involucral bracts acuminate, ovate-lanceolate, sparsely arachnoid, purple. Corolla dark violetpurple, tubular, $1.5-1.8 \mathrm{~cm}$ long. Anther tails lacerate. Cypsela cylindrical, brown, curved, compressed, 0.6-1 cm long. Pappus brown, feathery, plumose, $1.3-1.9 \mathrm{~mm}$. 

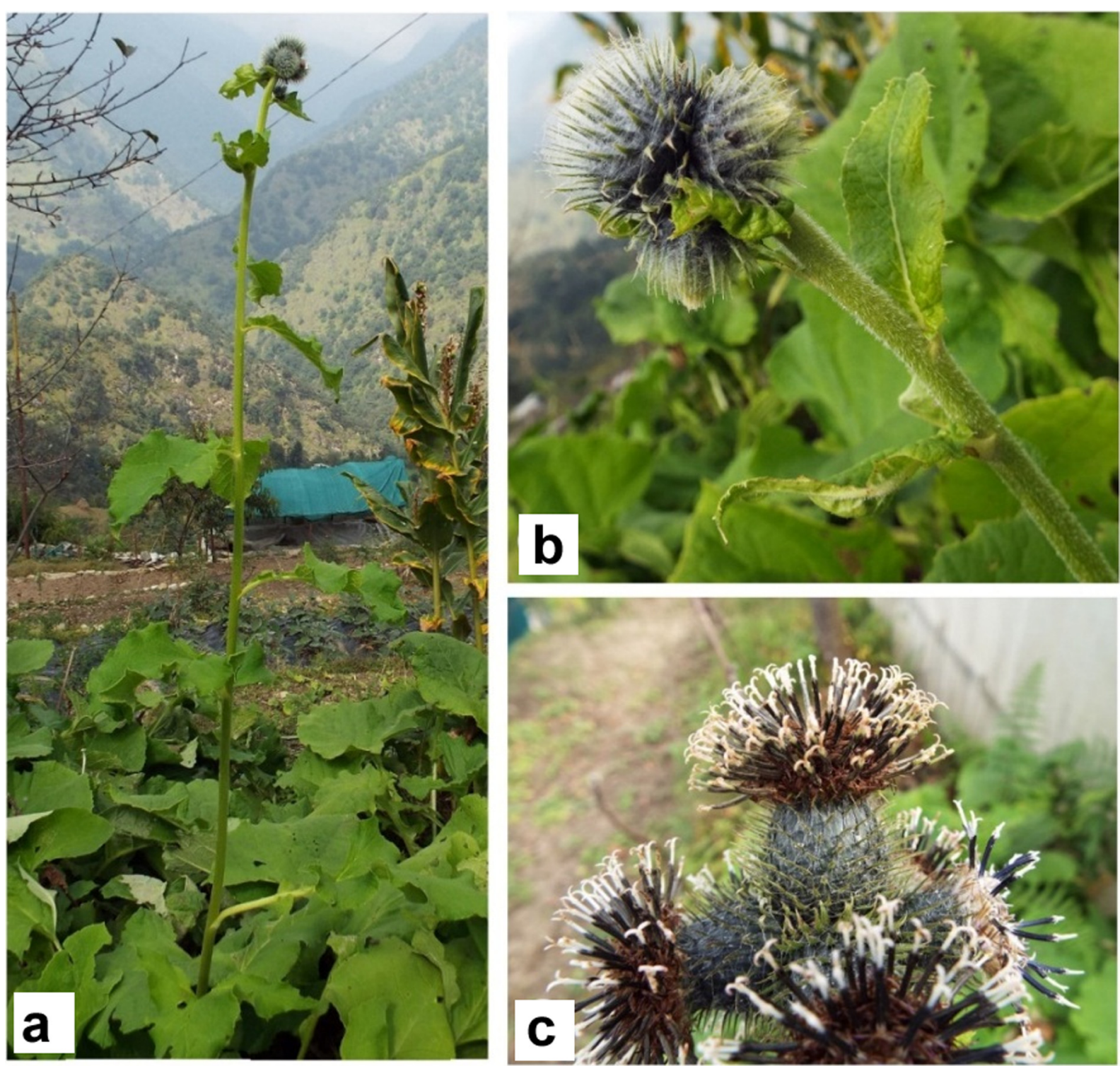

Fig. 3. Dolomiaea costus (Falc.) Kasana \& A.K.Pandey: a. Habit; b. Pubescent stem; c. Cluster of capitula (images by S. Kasana).

Flowering \& fruiting: Flowering and fruiting from July to October.

Habitat: Grows on rocky slopes and is widely cultivated due to its immense medicinal properties. It is found at elevations from 2100 to $4500 \mathrm{~m}$.

Distribution: China (cultivated), India and Pakistan. Specimens examined: INDIA, Himachal Pradesh, Chamba district, Pangi Valley, Sural, 3200 m, 18.07.2010, Pawan K. Rana 30612 (PUN); Kinnaur district, Chitkul, 17.08.1973, K.P. Janardhanan 52774 (BSD); Nichar, 2300 m, 28.05.1962, N.C. Nair 22065 (BSD); Upper Bashahr Forest Division,
MFP Branch 01.09.1951, s.coll. (DD); Kullu district, Kullu, Jalori pass, 3300 m, 10.06.1990, Daya Singh 16422 (PUN); Lahul Spiti district, $3000 \mathrm{~m}$, 01.09.1961, N.C. Nair 16669 (DUH); Lahul, Koksar, 05.09.1985, P.K. Hajra 76995 (BSD); Koksar (cult.), 3200 m, 02.08.1971, U.C. Bhattacharyya 44987 (BSD); Sissu, $3500 \mathrm{~m}$, 26.06.1958, M.A. Rau 5919 (BSD); Sissu, 3079 m, 05.07.1938, N.L. Bor 12320 (DD); Jahlma, Nalda Jasrath reserve, Pattan valley, 2896 m, 10.06.1958, S.P. Sethi \& R.S. Negi 304 (DD); Kyelong, 3139 m, 14.07.1941, N.L. Bor 9934 (DD); Mandi district, Chhatru, 3375 m, 05.09.1961, N.C. Nair 16669 
(BSD); Jammu and Kashmir, Thajwas mountains, 3800 m, 18.06.1959, T.A. Rau 9563 (BSD); Kunpathri in Tilal, $3048 \mathrm{~m}, 13.08 .1909$, Keshavanand 1515 (DD); Kashmir, 01.08.1891, J.C. McDonell s.n.(DD); Badzulkod nullah, Liddar valley, 3962 m, 01.08.1893, J.F. Duthie s.n. (DD); Liddar valley, 3353 m, 21.07.1993, J.F. Duthie 13106 (DD); Jaju Basa to Guric, 26.09.1838, Falconer's collectors s.n. (DD); Kamri pass, 3962 m, 01.08.1892, s.coll. 12582 (DD); Ramban, 27.06.1925, Shor Singh s.n. (DD); Sind valley, 3048 m, 13.08.1883, J.F. Duthie 13584 (DD); Keyan forest, Kawnah basin, Kishanganga valley, $2743 \mathrm{~m}, 12.07 .1906$, Keshavanand 207 (DD); Kilshai Bala in Tilai, 3353 m, 25.08.1909, Keshavanand 1576 (DD); Kishanganga valley, Shakhara stream, Jagram forest, 3353 m, 05.08.1906, Keshavanand 355 (DD); Baltistan, Dras valley, 3353 m, 22.08.1893, J.F. Duthie s.n. (DD); Sonmarg, Sind valley, $2743 \mathrm{~m}$, 05.08.1891, G.A. Gamma s.n. (DD); Srinagar, Dhara Mahadev, 2944 m, 16.06.2015, Sumeet Kour 2317 (KASH); Sonmarg, 2700 m, 10.09.1975, A.R. Azad 1136 (KASH); Kashmir, Simthan quarter, 3700 m, 26.07.1974, Gurcharan Singh 2914 (KASH); Pir Panjal range, $3010 \mathrm{~m}, 12.07 .1975$, s.coll. 1356 (KASH); Kashmir, Diison nala, 3100 m, 12.09.1988, Shoukat Ara 21 (KASH); Uttarakhand, Chamoli district, Dronagiri, P.K. Hajra \& Bipin Badoli 87551 (BSD); Chamoli, North of Bumpa, $3800 \mathrm{~m}$, 06.09.1975, B.D. Naithani 56102 (BSD); Gharwal district, Buhna, 3500 m, 15.06.1959, M.A.Rau 10209 (BSD); Rudraprayag district, Triyuginarayan, GB Pant NIHE, Rural Technology Centre, 2000 m, 05.10.2017, Shruti Kasana 1743, 1744 (DUH).

Conservation status: The species is in high demand due to the presence of bioactive compounds such as Costunolide and Cynaropicrin (Pandey et al., 2007) and is listed in Appendix I of CITES. It is overharvested for its aromatic roots and it has been reported that the natural population is decreasing rapidly (Anonymous, 2011; Sharma et al., 2019). This species is assessed as Critically Endangered [CR A2(c,d)] in the IUCN Red List of Threatened Taxa. In our field explorations also, we came across only one population in the wild (near Lahaul-Spiti, Himachal Pradesh) but found the species in cultivation at various locations.

Notes: Victor Jacquemont made extensive collections for the Museum d' Histoire Naturelle to the East for Voyage dans l'Inde and his specimen from Kashmir, India, is the original material for Aplotaxis lappa. In the protologue, only the collection locality is mentioned and no type was designated. A thorough search for the original material at BR, P, PC and G, where Jacquemont's collections are reportedly located revealed one of the original material agreeing well with the protologue (Jacquemont 727 at P [P00602864 digital image!]) and is hence designated here as the lectotype following Art. 9.3 of the Shenzhen code (Turland et al., 2018).

Dolomiaea macrocephala DC. ex Royle, Ill. Bot. Himal. Mts. [Royle] pt. 5: t.57. 1835. Carduus macrocephalus Desf., Fl. Atlant. 2: 245. 1799. Carduus macrocephalus Wall., Numer. List [Wallich] n. 2904. 1831. nom. nud. Saussurea religiosa Royle, Ill. Bot. Himal. Mts. [Royle] pt. 8: 251. 1835; Carduus nepalensis Spreng. ex DC., Prodr. [A.P. de Candolle] 6: 542. 1838: Jurinea macrocephala (DC. ex Royle) Benth. ex C.B.Clarke, Compos. Ind. 237. 1876, nom. illeg. Jurinea dolomiaea Boiss. Fl. Orient. (Boisser) 311. 1888. Jurinea himalaica R.R.Stewart, Fl. W. Pakistan Annot. Cat. 757. 1972, nom. illeg. Jurinella macrocephala (DC. ex Royle) Aswal \& Goel, Indian J. Forest. 11(4): 339. 1989. Lectotype (designated here): INDIA, Gosain Than, Kumaon, Wallich 2904 (E [E00394933 digital image!]). Isolectotypes: (G [G00474692, G00474688 digital images!], P [P00705232 digital image!]).

Jurinea himalaica var. tibetica R.R.Stewart, Fl. W. Pakistan 757. 1972. Jurinea dolomiaea var. tibetica (R.R.Stewart) H.B.Naithani, Fl. Pl. India, Nepal \& Bhutan 230. 1990. Jurinella macrocephala var. tibetica (R.R.Stewart) Karthik. \& Moorthy, Fl. Pl. India 242. 2009. Type: Baltistan, Burji La, 12000 ft, Clarke 29887A (Holo K [not seen]).

Figs. 4 \& 5

Perennial herbs, acaulescent. Leaves petiolate, oblong-obovate, 20-30 cm long, lobes pinnatifid, 

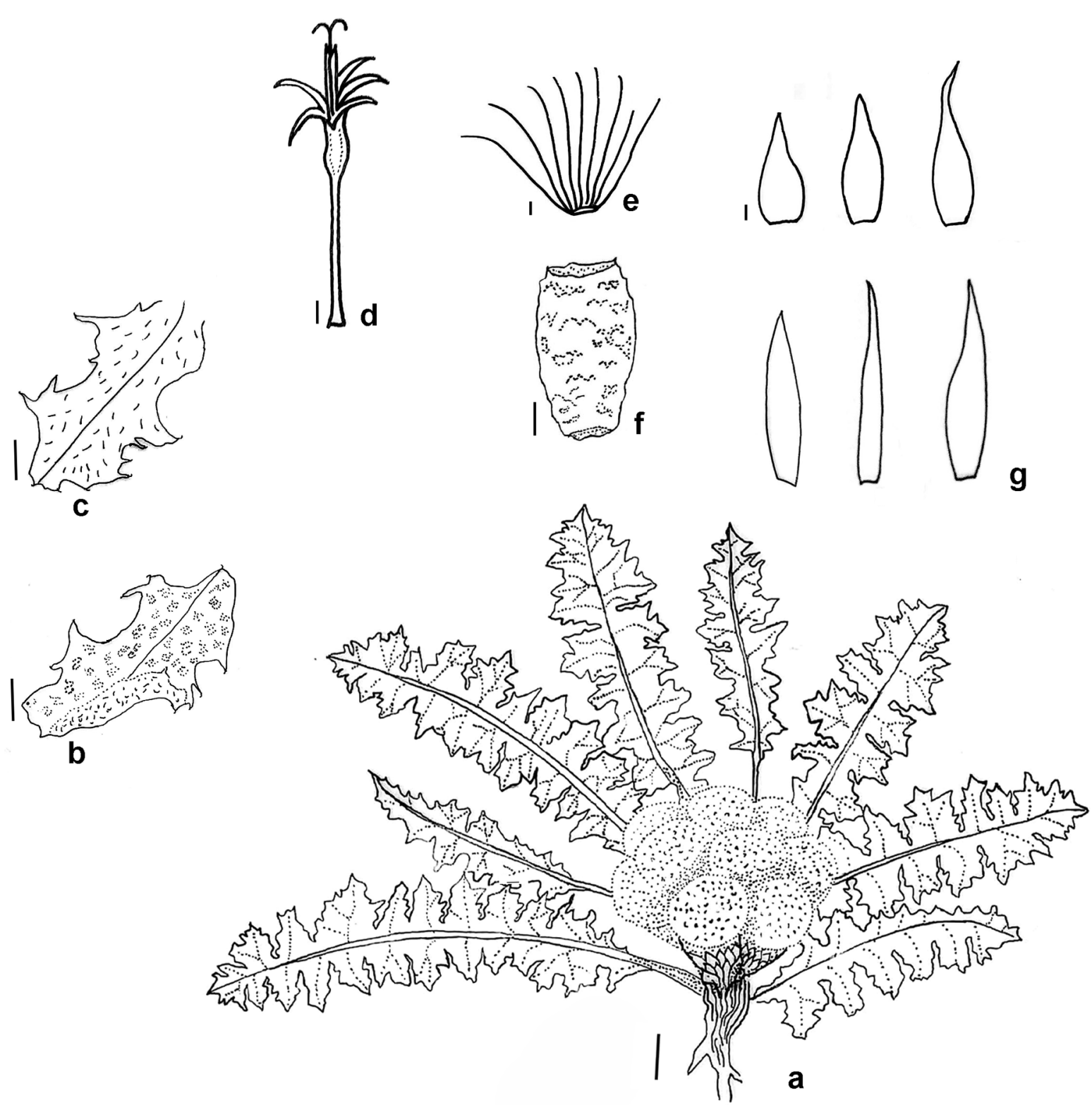

Fig. 4. Dolomiaea macrocephala DC. ex Royle: a. Habit; b. Enlarged portion of leaf with densely woolly abaxial surface; c. Enlarged portion of leaf with hirsute adaxial surface; d. Floret; e. Pappus; f. Cypsela; g. Involucral bracts. [scale =1mm (b-g); $2 \mathrm{~cm}$ (a)] (from S. Kasana 1713; drawn by S. Kasana).

denticulate, adaxial surface hirsute, abaxial densely woolly. Capitula numerous, 3-15 in number, sessile to shortly peduncled, $4-5 \times 2.5-3.2 \mathrm{~cm}$, tomentose. Involucral bracts multiseriate, ovate to ellipticlanceolate, scabrid, scarious. Corolla tubular, linear, 2-3.5 cm long, purple. Filaments glabrous. Anther base caudate; tails lacerate. Cypsela obovate, compressed, curved, glabrous, with black wavy fringes, apex truncate. Pappus plumose, brown, deciduous as a whole.
Flowering \& fruiting: Flowering and fruiting from July to October.

Habitat: Grows in alpine meadows, on rocky slopes and in rock crevices, at elevations from 3500 to $4600 \mathrm{~m}$.

Distribution: India, Nepal and Pakistan.

Specimens examined: INDIA, Uttarakhand, Rudraprayag district, Tungnath, $3650 \mathrm{~m}$, 03.10.2017, Shruti Kasana 1713, 1714 (DUH); 

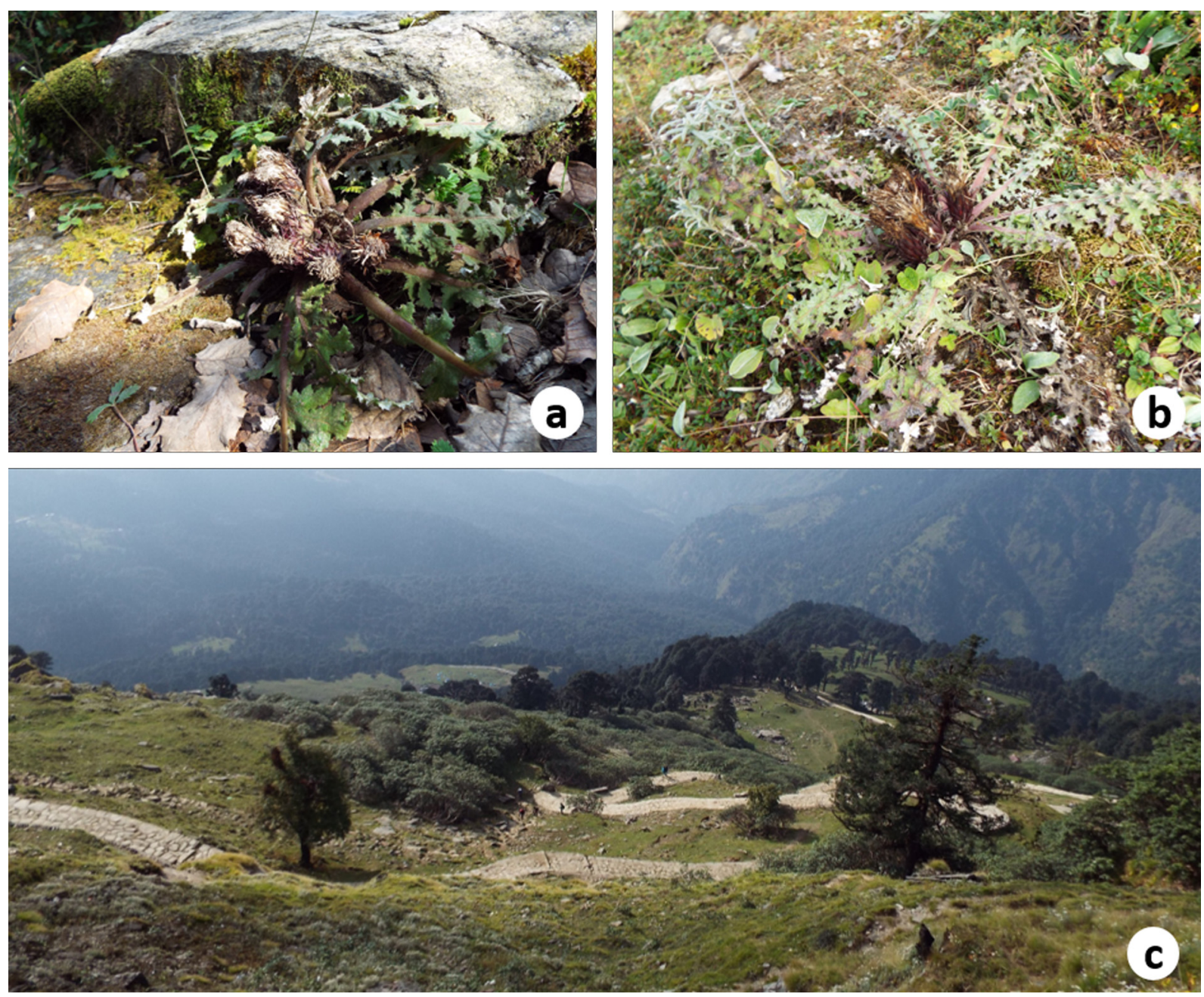

Fig. 5. Dolomiaea macrocephala DC. ex Royle: a \& b. Habit; c. Habitat (images by S. Kasana).

Garhwal, near Chandrashila peak, $4090 \mathrm{~m}$, 03.10.2017, Shruti Kasana 1735 (DUH).

Conservation status: During our field visits (from 2017-2020), we observed the species to be of occasional distribution but the population size has decreased over these years possibly due to over exploitation for its medicinal properties. We have also observed that its natural habitat is under threat due to increased tourist influx, leading to a decline in its extent of occurrence and the number of populations. Therefore, as the species is facing high risk of extinction from the wild, it has been assessed here as Vulnerable [Criterion B1 a,b(i,ii,iv)] following the guidelines of IUCN (2019).

Notes: Candolle described Dolomiaea macrocephala based on Wallich's collection (Catalogue No. 2904) from India, Gosain Than, Kumaon. However, he did not designate the type or mention the herbarium where the specimen was kept. We traced four original materials at three different herbaria: $\mathrm{E}$ (E00394933 digital image!), G (G00474692, G00474688 digital images!) and P (P00705232 digital image!). As the specimen at E (E00394933) agrees well with the protologue, we designate it as the lectotype following Art. 9.3 of the Shenzhen code (Turland et al., 2018).

The placement of this species in genus Dolomiaea was unclear and many authors (Hooker, 1881; Pusalkar \& Singh, 2012; Singh \& Pusalkar, 2020) accepted it under the genus Jurinea. This confusion arose due to the transfer of D. macrocephala to Jurinea by Pierre Edmond Boissier in 1888. When Boisser transferred the species, the epithet 'macrocephala' was 
preoccupied within Jurinea and hence, a replacement name was given as Jurinea dolomiaea Boiss. By applying this taxonomic change, the type of genus Dolomiaea was implicitly excluded by Boissier and hence the genus Dolomiaea was left with no type. This increased the existing confusion within Saussurea s.l. (now known as subtribe Saussureinae). However, recent molecular work (Herrando-Moraira et al., 2020) has clearly shown that this species lies in the Dolomiaea clade. Also, detailed morphological investigation shows that it should belong to Dolomiaea rather than Jurinea due to the absence of scales on the receptacle and yellowish pappus bristles that are not inserted on a conic cupule in Dolomiaea as compared to the presence of short scales on the receptacle and white pappus bristles that are inserted on a conic cupule in Jurinea.

\section{Acknowledgements}

Authors are thankful to the Herbarium curators of DD, BSD, KASH and PUN for permission to consult the herbarium specimens. Thanks are due to Dr. Kanchi N. Gandhi (Harvard University) for his help in clarifying nomenclatural doubts. SK is thankful to the Council of Scientific and Industrial Research, New Delhi, India for the award of a Senior Research Fellowship.

\section{Literature Cited}

ANONYMOUS 2011. A review of the status of Saussurea costus. In: Convention on international trade in endangered species of wild fauna and flora, nineteenth meeting of the plants committee held at Geneva (Switzerland). pp 1-19.

BENTHAM G. \& J.D. HOOKER 1873. Genera plantarum: ad exemplaria imprimis in Herberiis Kewensibus servata definita. Volume 2. L. Reeve \& Co., London. pp.473474. https://doi.org/10.5962/bhl.title.747

BHATTACHARYYA S., ADHIKARI B.S. \& G.S. RAWAT 2013. Forage selection by Royle's pika (Ochotona roylei) in the Western Himalaya, India. Zoology 116(5): 300-306. https://doi.org/10.1016/ j.zool.2013.05.003

BOISSIER P.E. 1888. Flora Orientalis sive enumeratio plantarum in Oriente a Graecia et Aegypto ad Indiae fines hucusque observatum [Supplement]. R.Buser, Geneva \& Basel.

CANDOLLE A.P. DE 1833. Genres nouveaux appartenant à la famille des Composées ou Synantherées. In: GUILlEMIN J.B.A. (ed.), Archives de Botanique, Volume 2. Au bureau des archives, Paris, pp. 330-384.

CHU S. 1986. On circumscription of genus Dolomiaea DC. Acta Phytotaxonomica Sinica 24(4): 292-296.

FUNK V.A., SUSANNA A., STUESSY T.F. \& H. ROBINSON 2009. Classification of Compositae. In: FUNK V.A., SUSANNA A., STUESSY T.F. \& R.J. BAYER (eds.), Systematics, evolution, and biogeography of Compositae. International Association for Plant Taxonomy, Vienna. pp. 171-189.

HAJRA P.K. 1995. Tribe Cardueae. In: HAJRA P.K., RAO R.R., SINGH D.K. \& B.P. UNIYAL (eds.), Flora of India, Volume 12. Botanical Survey of India, Calcutta. pp. 150-226.

HERRANDO-MORAIRA S., CALLEJA J.A., CHEN Y.S., FUJIKAWA K., GALBANY-CASALS M., GARCIAJACAS N., KIM S.C., LIU J.Q., LÓPEZ-ALVARADO J., LÓPEZ-PUJOL J., MANDEL R., MEHREGAN I., ROQUET C., SENNIKOV A.N., SUSANNA A., VILATERSANA R. \& L.S. XU 2020. Generic boundaries in subtribe Saussureinae (Compositae: Cardueae): insights from Hyb-Seq data. Taxon 69(4): 694-714. https://doi.org/10.1002/tax.12314

HIJMANS, R. J., GUARINO L., BUSSINK C., MATHUR P., CRUZ M., BARRENTES I., \& E. ROJAS. 2004. DIVA GIS. A geographic information system for the analysis of species distribution data. Manual available at: http://www.diva gis.org.

HOOKER J.D. 1881. Flora of the British India. Volume 3. L. Reeve \& Co., London.

HUANG R. 1988. The vascular flora of the QomolangmaXixabangma region, Tibet. GeoJournal 17: 625-633. https://doi.org/10.1007/BF00209447

IUCN 2019. Guidelines for Using the IUCN Red List Categories and Criteria. Version 14. Prepared by the Standards and Petitions Committee. Available at: http:/ /www.iucnredlist.org/documents/RedList Guidelines. pdf (Accessed on 30.09.2020).

KASANA S., DWIVEDI M.D., UNIYAL P.L. \& A.K. PANDEY 2020. An updated circumscription of Saussurea (Cardueae, Asteraceae) and allied genera based on morphological and molecular data. Phytotaxa 450: 173-187. https://doi.org/10.11646/phytotaxa.450.2.3

LI C.L. \& J. SHENG. 2013. Chemical constituents and antiacetylcholinesterase activities of Dolomiaea wardii. Advanced Materials Research 634-638: 901-904. https:// doi.org/10.4028/www.scientific.net/AMR.634-638.901 
LING Y. 1965 Genera nova vel minus cognita familiae compositarum, I. Vladimiria Ilj., Diplazoptilon Ling et Dolomiaea DC. Acta Phytotaxonomica Sinica 10(1): 75-91.

LIPSCHITZ S.J. 1979. Rod Saussurea DC. (Asteraceae). Nauka, Leningrad.

PANDEY M.M., RASTOGI S. \& A.K.S. RAWAT 2007. Saussurea costus: botanical, chemical and pharmacological review of an ayurvedic medicinal plant. Journal of Ethnopharmacology 110: 379 -390. https:// doi.org/10.1016/j.jep.2006.12.033

PUSALKAR P.K. \& D.K. SINGH 2012. Flora of Gangotri National Park, Western Himalaya, India. Botanical Survey of India, Kolkata.

RAAB-STRAUBE E. VON 2017. Taxonomic revision of Saussurea subgenus Amphilaena (Compositae, Cardueae). First Edition. BGBM Press, Berlin.

SHARMA P.K., CHAUHAN N.S. \& B. LAL 2004. Observations on the traditional phytotherapy among the inhabitants of Parvati valley in western Himalaya, India. Journal of Ethnopharmacology 92(2-3): 167-176. https:// doi.org/10.1016/j.jep.2003.12.018

SHARMA S., SHARMA R., SHARMA P., THAKUR K. \& B. DUTT 2019. Direct shoot organogenesis from seedling derived shoot tip explants of Endangered Medicinal Plant Saussurea costus (Falc.) Lipsch. Proceedings of National Academy of Sciences, India, Section B Biological Sciences 89: 755-764. https://doi.org/ 10.1007/s40011-018-0983-z

SHEN J., ZHANG X., LANDIS J.B., ZHANG H., DENG T., SUN H. \& H. WANG 2020. Plastome evolution in Dolomiaea (Asteraceae, Cardueae) using phylogenomic and comparative analyses. Frontiers in Plant Science 11: 376. https://doi.org/10.3389/fpls.2020.00376

SHI Z. \& E. VON RAAB-STRAUBE 2011. Cardueae. In: WU Z.Y., RAVEN P.H. \& D.Y. HONG (eds.), Flora of China, Volume 20-21 (Asteraceae). Science Press, Beijing \& Missouri Botanical Garden Press, St. Louis.

SINGH D.K. \& P.K. PUSALKAR. 2020. Floristic Diversity of the Indian Himalaya. In: DAR G.H. \& A.A. KHUROO (eds.), Biodiversity of the Himalaya: Jammu and Kashmir State. Topics in Biodiversity and Conservation, Volume 18. Springer, Singapore. pp. 93-126

SUSANNA A. \& N. GARCIA-JACAS 2009. Cardueae (Carduoideae). In: FUNK V.A., SUSANNA A., STUESSY T.F. \& BAYER R.J. (eds.), Systematics, evolution, and biogeography of Compositae. International Association for Plant Taxonomy, Vienna. pp. 293-313.

TURLAND N.J., WIERSEMA J.H., BARRIE F.R., GREUTER W., HAWKSWORTH D.L., HERENDEEN P.S., KNAPP S., KUSBER W.H., LI D.Z., MARHOLD K., MAY T.W., MCNEILL J., MONRO A.M., PRADO J., PRICE M.J. \& G.F. SMITH (eds.) 2018. International Code of Nomenclature for algae, fungi, and plants (Shenzhen Code) adopted by the Nineteenth International Botanical Congress Shenzhen, China, July 2017. Regnum Vegetabile 159. Koeltz Botanical Books, Glashütten. https://doi.org/10.12705/ Code.2018

WANG Y.J., LIU J.Q. \& G. MIEHE 2007. Phylogenetic origins of the Himalayan endemic Dolomiaea, Diplazoptilon and Xanthopappus (Asteraceae: Cardueae) based on three DNA regions. Annals of Botany 99: 311322. http://dx.doi.org/10.1093/aob/mcl259 